\title{
Socio-Economic Status of the Street Children in Bangladesh
}

\author{
Sheikh Abir Hossain \\ Staff Researcher, Institute of Educational Development, BRAC University, Bangladesh \\ 113/A, Road 2, Block A, Niketon, Gulshan 1, Dhaka 1212, Bangladesh \\ E-mail: sk.abir@hotmail.com
}

Md. Ashraful Alam

Assistant Professor, Institute of Social Welfare and Research, University of Dhaka, Bangladesh

Institute of Social Welfare and Research, University of Dhaka, Dhaka 1000, Bangladesh

E-mail: ashraful.iswrdu@gmail.com

Received: December 2, 2015 Accepted: January 6, 2016 Published: January 8, 2016

doi:10.5296/ijsw.v3i1.8668 URL: http://dx.doi.org/10.5296/ijsw.v3i1.8668

\begin{abstract}
Basically, the children who are in situations of poverty, illiteracy, disease and social injustice have been focused on this study and have been prioritized those children who sleep on streets, railway terminals and platforms, bus stations, parks and open spaces, religious centers, construction sites and around graveyard and in other public places with no roof in scale. A survey has been conducted on a sample of 101 children from two purposively selected areas of Dhaka city to gather information on their Socio-economic status by using quantitative method. Findings reveal that the street dwellers had to adopt a very precarious and humiliating life on the streets devoid of all basic amenities of life, under constant threat of eviction and harassment by the bad people and hoodlums. They work hard to meet their demands but due to their involvement in low paying informal sector, their demands are hardly filled out. They cannot improve their conditions at all even after five or more years of street-living. According to them, housing, food, and lack of jobs are the three most common problems for which they are to seek assistance and to live in the street for unknown period.
\end{abstract}

Keywords: Socio-economic status, Street children, Dhaka city 


\section{Introduction}

Children are the great asset for a nation because the after-life of a nation largely depends on the children. So they are called the father of any nation (Taher, 2006). The reflection of hope and aspiration of any nation can be ensured by the children. They can play the role of spraying welfare and peace among the nation. Whether the children will fill out the hope of the nation or not that depends on their proper nursing other facilities ensured by the state or country. Thinking these, they are prioritized from the dawn of civilization (Hurlock, 1972). There has been an alarming rise in the number of street children in the major cities of Bangladesh. The increase is linked to recent figures released by the government which show that the urban population of Bangladesh continues to grow by around nine percent a year (Khan, 1999). Being smashed by the sorrow and suffering, the village people leave their home and come to city hoping to have one-fold food. Natural calamities such as cyclone, drought, river erosion etc do not permit them to live in peace rather snatch their life-long earned properties and compel them to leave their locality (Hossain, 2001). Coming to city, they take shelter beside the roads, railways, in the park, slums etc. During living in these places, they give- birth children who are not nursed and taken care well (UNICEF, 1996). These children do not get basic needs prioritizing food, cloth, medicine, residence, education etc (Islam, 2010). They get ages moving street to street and with the consequences of both urbanization and industrialization, street children are getting deprived of every facility and compelled to engage themselves in various hard work for earning livings for themselves and their families. Basically behind being street children, the common causes are ; lack of food, loss of land, for a better life, lack of opportunities, broken family, step-parents and so on (Kabir,1999). The reason of becoming street children is mainly economic. As Bangladesh is a poor country, majority people here live under poverty line. So many people come to Dhaka city on search of livelihood from the remote corner of the country, but they fail to manage any work (Zahiduzzan, 1998). As a result the people start to live under open sky. Many of them cannot effort to buy food for their family so the children of those families start working. Other hardship such as, absence of an earning member in the family, death of parents etc also lead street children. A majority of the street children (30\%) live with their parents in Dhaka city (Aparajeyo Bangladesh, 2011).

\section{Objectives of the Study}

The specific objectives of this study are

- To find out demographic features of the street children.

- To reveal the causes of their coming to Dhaka

- To highlight their ways of living and portrait the present living condition

- To find out the difficulties faced by the street children.

- To know their aspirations in respect of changing their lives

\section{Research Methodology}

The study followed quantitative method that helped combine quantitative data. Data of the study was collected from both primary and secondary sources (Miles \& Huberman, 1984). In addition, primary data was collected from selected samples through Survey method. On the 
other hand, secondary data was gathered from published and unpublished research reports, journals, books, as well as from record and documents of relevant agencies. Besides, the part of different areas prioritizing Azimpur and Lalbagh under Dhaka district of Bangladesh was selected as areas where most of the street children are found to live and it has been chosen on the basis of purposive sampling. Moreover, a sample of 101, Azimpur (51) and Lalbagh (50), street children were selected for the study. Furthermore, all the street children aged 5-18 was considered the research population. Then, the collected data from the research areas was analyzed. Finally, it has been classified according to its characteristics and presented according to the emerged themes.

\section{Overall Findings}

\subsection{Demographic Features}

The respondents were between 13-14 years of age: The research considers the street children who were 6-18 years of age and able to provide data for the study. It revealed that most of the street children were between 13-14 years of age and they were the highest percent also (35.5\%). According to Taher (2006), most of the street children coming from rural areas to urban areas were between 13-14 years of age and more or less were able to give logical information standing by which a researcher could conduct a research. Our study also got that the respondents (street children) were between 13-14 years old and able to provide essential information.

The respondents were male and unmarried: In gender distribution, the higher numbers were male $(88 \%)$ and the rest were female $(12 \%)$. Among the respondents $62.5 \%$ was unmarried and only $15 \%$ was married. The study of Sumaiya (1998) got that most of the purposively selected respondents (street children) in the city areas were male and most of them were unmarried as well. The conducted study by us also got that most of the street children living in different areas in the Dhaka city were male and unmarried.

The respondents were under the guidance of mother: $50 \%$ of the respondents were under the guardianship of their mother and only $27.5 \%$ was under the guardianship of their fathers. $37 \%$ of the respondents came to Dhaka with their mothers and $27.55 \%$ came alone. According to Kabir (1999), the street girl children used to live under the guidance of their mothers in most cases. On the contrary, our study found that most of the street children were under the guidance of their mothers.

\subsection{Causes of Coming to Dhaka}

The respondents came for abysmal poverty: $32.5 \%$ of the respondents came to Dhaka in search of work on the other $27.5 \%$ came for the biting of poverty. $40.9 \%$ of the respondents came for their want and $18.18 \%$ came willingly fleeing. The study of Islam (2010) found that majority of the street children coming from different areas to the city areas were under the strong clutch of poverty and for that reason they came to city areas. On the other hand, our study got that most of the street children came to Dhaka only for acute poverty and they were violently affected by this to come to Dhaka. 


\subsection{Ways of Living and Portrait the Present Living Condition}

The respondents would live on footpath and take drugs: $37 \%$ of the respondents would live on footpath and the rest part live in park and railway station. $37.5 \%$ respondents used to take drugs and the rest did not take drugs if taken that were cigarette. The study of UNICEF (1997) found that most of the street children would pass their daily lives living on footpath and most importantly they were vehemently affected by drugs even could not abstain from taking drugs in a single day. Our study got that most of the street children used to live on footpath and pass their lives there. Alongside this, most of them were directly or roundabout used to take drugs.

The respondents would pass leisure time by gossiping: $30 \%$ of the respondents would pass their leisure time through gossiping and $27.5 \%$ passed their leisure time through playing. The study of BBS (2011) got that majority of the street children were habituated to passing their leisure time through gossiping and it was only of the ways for passing their time for recreation. Our study found as well that most of the street children living in Dhaka city used to pass their leisure time only through gossiping and for many of them it was the only way to have recreation.

The respondents earned below their demand but would have three times meal: Around 17.5\% of the street children earned within 51-60 taka and the rest part earned below 30 taka per day. $87.5 \%$ of the street children got three times meals in a day. $27 \%$ of the respondents involved in begging and flower selling. Twenty percent of the respondents would work as a labour and tokai (the person who collects different broken, torn and unusable materials and sells them to market for livelihood is called Tokai). The study of Annan (Annan, 1999) found that the street children both male and female could not afford to earn their livings as per their demands but they would manage three times meal by themselves or by others. Our study also got that most of the street children living in Dhaka city would not afford to earn their demands they need rather it was below their demand but they would manage three times meal.

\subsection{The Difficulties Faced by the Street Children}

The respondents faced severe problems: $82.5 \%$ of the respondents would face many problems in different aspects and $17.5 \%$ face fewer problems. The vast portion of the respondents $(92.5 \%)$ was in torture and $7.5 \%$ of the street children was free from torture.18.18\% of them was abused by local terrorist and $27.27 \%$ was abused by others (unknown). The study of Zahiduzzaman (1998) found that many of the street children in city areas in Bangladesh faced problems a lot and were tortured violently by others that were really against children rights. Our study got that most of the street children living in Dhaka city were tortured by others who were unknown to them.

\subsection{Aspirations of the Street Children in Respect of Changing Their Lives}

The respondents longed for education: $14.29 \%$ of the respondents wanted to save huge money for their future while $10.72 \%$ wanted to be a businessman. $15.96 \%$ of the respondents wanted to have educational facilities right now and only $10.64 \%$ wanted rehabilitation facilities. According to the study of Hossain (2001), Majority of the street children thought that lack of education was the only debacle in respect of changing their conditions and they 
wanted to have education in that respect. Our study also found that most of the street children thought that it was only lack of education for which their conditions were poor and they expected education with emphasis for changing their poor economic conditions.

\section{Recommendation}

The street children are deprived of their basic necessities. Because of family disorganization, extreme poverty, river erosion, tortured by step father or mother, cheated by someone the children come to Dhaka for their survival from different areas of the country (Kabir, 1999). The number of street children is increasing day by day. In this way they cannot fulfill their basic necessities moreover they are used economically, socially, politically by one class of people. They are physically tortured, sexually abused, psychologically ostracized by people (Bequele \& Myers, 1995). It is very much necessary to take proper and effective steps to protect the children from all types of violations, to ensure their basic necessities properly, to ensure their well growth and development of the street children. For fulfilling the purpose, some NGOs have taken various programs to give basic necessities to the street children but it has been observed that the overall situation of the street children is not developing (Mia, 1995). On the basis of the results of the research, some recommendations to improve their position, to ensure their rights and basic necessities, stop violence against them, all over ensuring well socialization and to make them as a good citizen for the country are given below:

- From the study, it is found that one of the important routs of being street children is extreme poverty which leads them rural-urban migration. It is a matter of policy in rural development, how those children can be accommodated in rural areas. A number of rural based development projects are now working in rural areas such as aged allowance, social safety net, reaching out of school children (ROSC) project under education for all, etc. In policy level, the Government can think to include these children, who are either excluded from the development projects or still not identified.

- The major cause of being street children has been identified as parents' vulnerable financial condition. It is now more important to improve their financial well-being. The Government and NGOs can introduce some income income-generation activities, which are locally fitted with their needs and demands.

- Mass awareness should be raised and general people should be sympathetic to the children in the street. They should behave well with the children, call them by their name, and give them informal education if possible.

- Bangladesh is a poor country. It is not possible to fulfill all the basic necessities of the people with the little amount of resources within a very short time span. For this, government faces a lot of problems. That is why Government, NGOs and philanthropic persons should be initiator to make a comprehensive and effective program for the street children.

- The government and non government organizations should come forward to take necessary steps for the street children to give them legal aid.

- The laws which are related with child right should have revised again and faults of the laws should be abolished. Legal reform for the children should be established. 


\section{Macrothink

- The people who are related with the violation of child rights, torture, and harassment should be strictly punished. Laws related with this, should be applied.

- Street girl children are sometimes tortured and abused by the police, passer-by, hijackers etc. Besides they make wrong behave with them and inspire for the illegal activities. These people should be punished (Freeman, 1983).

- Prohibit the hazardous works for the children and assign the way of child labor.

- The number of street children is increasing day by day. These large numbers should be reduced to solve the problem. We know some NGO's are giving shelter home facilities to the street children, like Aporajayo Bangladesh, Dhaka Ahsania Mission are two of them (Kabir, 1999). More shelter homes should be built for the safe residence for the children. The shelter homes should have available facilities to ensure their basic necessities such as food, clothing, education, medical, recreational facilities.

- Street children should be given priority to take any types of program for the children because they are most vulnerable group.

- Demand, desire, rights of the street children in shelter home or in the street can be shown to all people of the country by mass awareness and it is possible by radio, television, newspapers etc. If the mass media make a documentary or short films for the street children then people would be aware with this and they will come forward to help them.

- Round table conference about the rights, desires of the street children can be arranged by the journalists to inform all the people of the country and where the street children can talk with the journalists and show their problems, desire, demand, history of life etc. By this way the people will be sympathetic to the street children.

- Overall the state and people from all stages of life should come ahead to solve the problem and take it as sensitive issue to make the street children as a well established citizen for the country.

\section{Conclusion}

The children are the dream of tomorrow. The street children are a part of the future dream of the nation. For lack of solvency and basic necessities street children cannot grow in the right way and that is why they are not growing as human resource of the country. So, for their overall development, ensuring their proper growth and development, protecting the future citizen of the country above recommendation should be given importance and effective programs should be taken right now. Though we tell high-sounding catch words about the pinnacle-like opportunities for the children living in the street, the real scenario is reverse. Thing is that most of the street children are not getting facilitated rather they are being connived from their dues violently. Notwithstanding the formulated laws, they are not entitled to the same beneficiaries as others. It is not formulated or written law but implemented law that can only ensure proper rights for the street children. Along with the government, NGOs and people in all walks should be more aware and submissive towards the street children so that they would be able to lead such a life as they expect like others. We have to bear in mind that Love should not be just a relationship it should be a state of being. 


\section{References}

Annan, K. A. (1999). The States of the World's Children. United Nations International Children's Emergency Fund (UNICEF). Dhaka.

Aporajayo Bangladesh. (2009). Annual Report. Dhaka.

Bangladesh Bureau of Statistics [BBS]. (2011). Bangladesh Population census. Ministry of planning, People's Republic of Bangladesh, Dhaka.

Bequele, A., \& Myers, W. E. (1995). First things First in Child Labor: Eliminating Work Detrimental of Children. UNICEF, Geneva.

Chowdhury, D. P. (1980). Child Welfare and Development. Delhi: Atmaram and Sons.

Freeman, M. (1983). The Rights and Wrongs of Children. London: Francis Printer Publishers.

Hossain, S. (2001). Research on Slums and Squatters in Bangladesh: A critical review. Social Science Review, University of Dhaka, Bangladesh.

Hurlock, E. B. (1972). Child Development. New Delhi: Prentice Hall.

Islam, M. R. (2010). A Child in the Family but imprisoned: Study on The Situation of Domestic Child Workers in Dhaka City, Bangladesh Shishu Adhikar Forum (BASF), Padakhep Printing \& packaging. Dhaka.

Kabir, R. (1999). Adolescent Girls in Bangladesh. United Nations International Children's Emergency Fund (UNICEF). Dhaka.

Khan, S. (1999). Study on Street Children. Save the Children (UK). Dhaka.

Md.,A.T.(2006). Child Labor in Dhaka City; Dimensions and Implications, Sangati printers, Dhaka.

Mia, Dr. A. (1995). Underprivileged Children's Educational Program (UCEP). Approach to Poverty Alleviation Promising Path. Dhaka.

Miles, M. B., \& Huberman, A. M. (1984). Qualitative and Quantitative data analysis: A sourcebook of new methods. Beverly Hills, CA: Sage.

Sumaiya, K. (1988). 'Taking Children's Rights Seriously: Areas of Concern' in Towards Gender Equity, Poverty, Rights sand Participation, Report of the Regional Workshop, (pp. 15-18) February, Dhaka; UNICEF, Children of Bangladesh and Their Rights, Dhaka.

United Nations International Children's Emergency Fund [UNICEF]. (1997). The State of World's Children. New York: UNlCEF and Oxford University press.

United Nations International Children's Emergency Fund [UNICEF]. (1996). The State of the World's Children. New York.

Zahiduzzaman, F. (1998). Women, children trafficking in Bangladesh. Dhaka: Kyodo Press. 


\section{Macrothink}

International Journal of Social Work

ISSN 2332-7278 2016, Vol. 3, No. 1

\section{Copyright Disclaimer}

Copyright reserved by the author(s).

This article is an open-access article distributed under the terms and conditions of the Creative Commons Attribution license (http://creativecommons.org/licenses/by/3.0/). 